\title{
Schistosomiasis haematobium
}

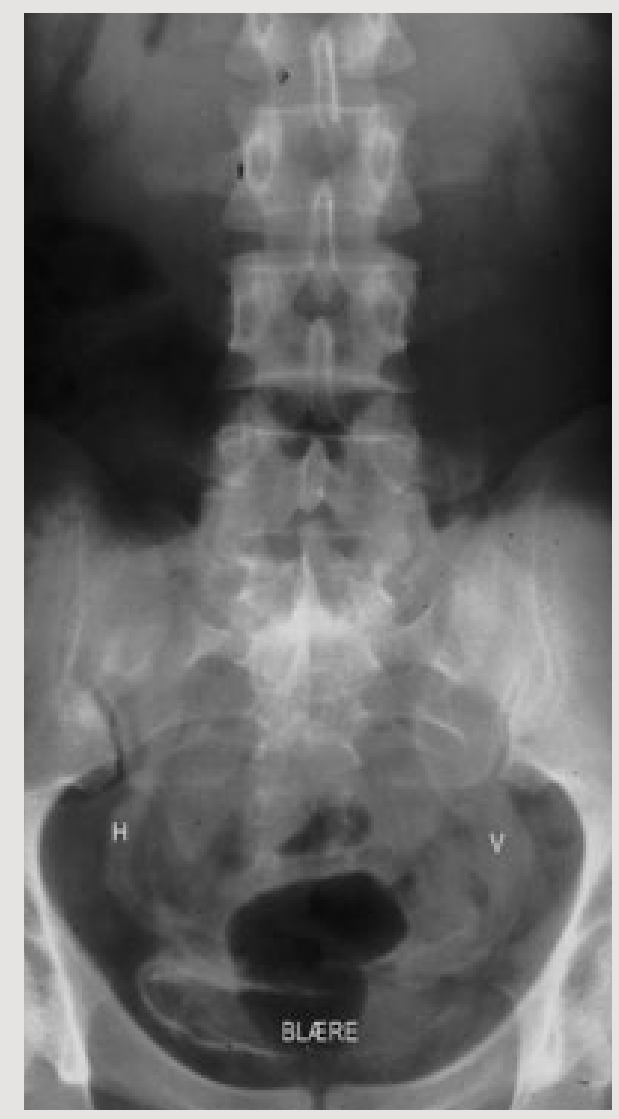

Bildet er et oversiktsrøntgenogram uten kontrast som viser et avansert stadium av schistosomiasis i urinveiene med utbredte veggforkalkninger i urinblæren og i utvidede urinledere $(\mathrm{H}, \mathrm{V})$. Mest utvidet er den venstre der forkalkningene følges opp til nivå med øvre rand av os sacrum.

Sykdommen skyldes en om lag $10 \mathrm{~mm}$ lang flatorm av genus Schistosoma. Fem spesies forårsaker alvorlig sykdom hos mennesket: S. mansoni, S. japonicum, S. mekongi og S. intercalatum som alle gir en hepatointestinal form, og S. haematobium som gir urogenital sykdom. Ifølge WHO er schistosomiasis på verdensbasis den viktigste parasittsykdommen etter malaria, og forekommer i Afrika, Asia og Sør-Amerika. WHO anslår at mer enn 207 millioner er infisert, $85 \%$ av disse i Afrika, herav mange barn.
Schistosomiasis haematobium finner vi i Afrika og Midtøsten. Parasitten har en komplisert livssyklus der mennesket er habitat og en ferskvannssnegle mellomvert. Egg som kvitteres til ferskvann med urin, omdannes til larver som i mellomverten blir til nye larver. Disse penetrerer huden til ubeskyttede personer i vannet og havner i leveren.

Etter modning i leveren finner ormen veien til urinblærens venepleksus, noen ganger også til det hemoroidale. Generelle symptomer skyldes reaksjon på eggene. Et fremtredende lokalt symptom er hematuri. Eggene induserer en reaktiv fibroserende prosess i blære og uretre med kalknedslag. Dette fører til avløpshinder i urinlederne med komplikasjoner i form av steindanning, sekundær infeksjon og nyresvikt. Tilstanden disponerer også for blærecancer.
Behandling med praziquantel, som er et vermicid, retter seg mot ormen, men brukes også forebyggende. Ved komplikasjoner er behandlingen hovedsakelig kirurgisk, eventuelt dialyse.

\section{Aksel Ongre \\ aksongr@online.no \\ $\mathrm{His}$}

Aksel Ongre (f. 1934) er pensjonert overlege, spesialist i radiologi. Consultant radiologist 15 måneder i Saudi Arabia i 1986-87. Ingen oppgitte interessekonflikter.

Mottatt 8.3. 2011, første revisjon innsendt 17.4. 2011, godkjent 5.5. 2011. Medisinsk redaktør Lars Frich. 